\title{
EVALUASI POTENSI SUMBERDAYA AIR UNTUK PENGEMBANGAN INDUSTRI DI KOTA BONTANG, KALIMANTAN TIMUR
}

Evaluation of Water Resource Potential for Industrial Development in the City Bontang East Kalimantan

Oleh :

Arie Herlambang

Balai Teknologi Lingkungan, BPPT

\begin{abstract}
Abstrak
Jumlah penduduk Bontang tahun 2014 sekitar 187.346 orang. Dengan tingkat kebutuhan air domestik 110 liter/orang/hari, kebutuhan air kota Bontang 238,52 liter/detik. Saat ini kebutuhan air masyarakat dipasok dari perusahaan air minum daerah (PDAM) dengan kapasitas 80 liter/detik, dan akan dikembangkan lebih lanjut sampai dengan 250 liter/detik pada tahun 2015. Ada dua industri besar yang membutuhkan air besar, yaitu LNG dan Pabrik Pupuk. Pabrik Kalimantan Timur (PKT) membutuhkan pasokan air tambahan sekitar $1.000 \mathrm{~m}^{3} / \mathrm{jam}$ atau 166,67 liter/detik dengan spesifikasi untuk Air Industri $800 \mathrm{~m}^{3} / \mathrm{jam}$ dan $200 \mathrm{~m} / \mathrm{jam}$ akan digunakan untuk memasok kebutuhan air untuk 21818 jiwa. Sumber air Kota Bontang berasal dari air tanah, sungai, dan penyimpanan air hujan (waduk). Dalam beberapa dekade terakhir Bontang mengandalkan air tanah untuk pasokan air industri dan domestik, sisanya menggunakan air sungai dan air tadah hujan. Dengan curah hujan yang tinggi (> $2500 \mathrm{~mm} /$ tahun), maka pembuatan kolam dalam jumlah besar dapat membantu menjaga cadangan air di masa'depan. Untuk itu diperlukan suatu kajian pemanfaatan sumber daya air yang potensial dan disesuaikan dengan rencana pengembangan kota. Daur ulang air limbah domestik juga merupakan sumber potensial untuk air tawar di masa depan, terutama untuk keperluan industri. Sistem drainase diarahkan pada kolam besar yang terletak di daerah yang rendah, sebelum sampai ke laut. Hujan yang turun di kota disalurkan dan dikumpulkan berpotensi jika dimanfaatkan. Dalam jangka pendek pemanfaatan air sungai Bontang sangat potensial, mengingat lokasinya di pusat kota dan merupakan salah satu dari daerah aliran sungai di Bontang yang menyebabkan banjir di musim hujan. Pengendalian dan pengelolaan air dibutuhkan untuk mendukung penggunaan air sungai.
\end{abstract}

Kata Kunci: Sumberdaya Air, Kebutuhan Air, Pemasokan Air, dan Neraca Air

\section{Abstract}

The total population Bontang in 2014 is around 187,346 peoples. With the level of domestic water demand of 110 liters /person/day, the water needs of the city for at least Bontang 238.52 liters/sec. Currently for the needs of the community water supply received from the local water company with a capacity of 80 liters/sec, and It will be developed further to 250 liters/second in 2015. There are two big industries that need huge of water, namely LNG and Fertilizers Factory. Factory of East Kalimantan (PKT) need additional water supply around $1000 \mathrm{m3} / \mathrm{h}$ or (166.67 liters/sec) with the specifications for the Water Industry and $200 \mathrm{m3} / \mathrm{h}$ will be used to supply the needs of water for 21 818 inhabitants. Bontang city water source can be derived from groundwater, rivers, and rain water storage (reservoirs of water). In recent decades Bontang relied upon groundwater for water supply industry and some communities, the rest use river water and rain water tandah. With a very heavy rainfall (> $2500 \mathrm{~mm}$ / year), then the making of ponds in large quantities can help to reserve water in the future. For the purposes of future water supplies, it would require an asessment of all potential water resources utilization and planning for the use of adapted to the urban development plan. Water recycling of domestic waste is also a potential source of fresh water in the future, especially for industrial use. The drainage system needs to be directed at a large holding pond located in a low area, before going into the sea. The rain that fell in the city drained and collected would be of potential if utilized. In short-term utilization of water of the Bontang river is very of potential, given its location in the city center and is one of the many watersheds in Bontang, causing floods in the rainy season. Control and management of water is needed to support the use of river water.

Keywords: Water resources, Water Demand, Water Supply, and Water Balance 


\section{LATAR BELAKANG}

Saat ini di dunia masih sekitar $52 \%$ penduduk miskin yang belum mempunyai akses terhadap air minum dan $44 \%$ penduduk belum mendapat pelayanan sanitasi yang baik, tingkat kematian terkait rendahnya pelayanan sanitasi masih tinggi di antara negera-negara Asia Tenggara. Saat dilangsungkan Millenium Summit pada bulan September 2000, Pemerintah Indonesia bersama 188 negara lainnya sepakat menandatangani Deklarasi Millenium PBB, sebuah program ambisius yang bertujuan untuk mengurangi kemiskinan, meningkatkan kesehatan dan pendidikan, mendorong adanya perdamaian, hak azasi manusia dan daya dukung lingkungan hidup. Pertemuan ini menghasilkan sekumpulan tujuan yang disebut dengan Millenium Development Goals (MDGs) dan sejumlah kebijakan khususnya yang musti terukur dan bisa dicapai di tahun 2015 (Anonim 12, 2012). Dengan target pencapaian MDGs, maka Sumberdaya Air menjadi penting tidak hanya untuk memenuhi kebutuhan masyarakat, namun diperlukan juga untuk menunjang kebutuhan industri terutama yang membutuhkan air dalam proses produksinya.

Letak Kota Bontang antara $117^{\circ} 23^{\prime}$ Bujur Timur - $117^{\circ} 38^{\prime}$ Bujur Timur serta di antara $0^{\circ} 01^{\prime}$ Lintang Utara $-0^{\circ} 012^{\prime}$ Lintang Utara. Wilayah Kota Bontang didominasi oleh lautan. Kota Bontang memiliki wilayah daratan seluas $147,8 \mathrm{Km}^{2}$ (29,70\%), sedangkan luas wilayah seluruhnya $497,57 \mathrm{Km}^{2}$. Jumlah penduduk Kota Bontang adalah sekitar 187.346 jiwa (Bontang Dalam Angka, 2012). Deigan tingkat kebutuhan air domestik sebesar 110 liÆer / orang/hari, maka untuk kebutuhan air kota Bontang minimal 20,6 juta liter/hari atau 238,52 liter/detik. Saat ini untuk kebutuhan air masyarakat mendapat pasokan dari PDAM kota dengan kapasitas 80 liter/detik, dan rencana akan dikembangkan lagi menjadi 250 liter/detik pada Tahun 2015 (Anonim 14, 2013).

Morfologi Kota Bontang berupa permukaan tanah yang datar, landai, berbukit dan bergelombang. Secara topografi kawasan Kota Bontang memiliki ketinggi anantara 0-120 meter di atas permukaan laut (mdpl) dengan kemiringan lereng yang bervariasi dan terdiri dari sebagian besar wilayah daratan dan beberapa wilayah berupa pulau-pulau kecil. Ditinjau dari kemiringan lerengnya, Kota Bontang memiliki kemiringan lereng yang bervariasi dari pantai Timur dan Selatan hingga bagian Barat. Kemiringan lahan datar antara 0\%-2\% mempunyai luasan 7.211 ha atau $48,79 \%$, Kemiringan lahan bergelombang antara 3\%-15\% seluas 4.001 ha atau $27,07 \%$, serta luas lahan dengan kemiringan curam antara 16\%-40\% hampir sama dengan luas bergelombang yaitu $24,14 \%$ atau 3.568ha.

Kondisi Geologi, Kota Bontang termasuk dalam sub bagian Cekungan Kutai dengan batas fisik di sebelah Timur Selat Makasar, sebelah Selatan Sungai Santan, sebelah perbukitan sebelah Timur Gunung Lobang Batik dan sebelah Utara Sungai Temputuk. Dari aspek litologi, formasi batuan di Kota Bontang terdiri dari enam formasi batuan, yaitu: a. Endapan Alluvium, b.Formasi Kampung Baru, c. Formasi Balikpapan, d. Formasi Pulau Balang, e. Formasi Bebulu, dan f. Formasi Pamaluan.

Formasi Kampung Baru yang tersusun atas batu pasir kuarsa dengan sisipan lempung, lanau dan serpih dengan sifat lunak dan mudah hancur. Formasi ini memiliki aquifer potensial di daerah Bontang dengan jenis batuan yang bertindak sebagai aquifer berupa kerikil, pasir kuarsa yang bersifat lepas, batu pasir dan pasir lempung. Berdasarkan ciri fisik litologi, fasies lingkungan pengendapan, struktur geologi dan batuan yang tersingkap di daerah Bontang dan sekitarnya, cekungan air tanah Bontang merupakan sub cekungan Kutai. Areal imbuh cekungan air tanah Bontang diperkirakan berasal dari daerah tekuk lereng Gunung Lobang Sebatik beserta areal perbukitannya yang memanjang dari Utara ke Selatan. Jalur tersebut ditempati oleh batuan dari Formasi Kampung Baru. Formasi ini bertindak langsung sebagai formasi peresapan paling potensial untuk cekungan air tanah Bontang (POKJA AMPL, 2011).

\subsection{Tujuan}

Tujuan penelitian ini adalah mengevaluasi potensi sumber air yang ada di Kota Bontang dan sekitarnya. Dengan mengetahui potensi sumber air, diharapkan dapat digunakan sebagai informasi dasar untuk mendukung keperluan pengembangan industri dan mencukupi kebutuhan air bersih masyarakat dan pertanian.Ruang lingkup evaluasi potensi sumber daya air meliputi sumberdaya air permukaan (sungai, danau dan rawa), air tanah dan potensi daur ulang air dari potensi air limbah.

\section{METODOLOGI}

\subsection{Persiapan Dan Peralatan}

Dalam pelaksanaan evaluasi ini dilakukan tahap persiapan dengan mencari data awal yang berupa hasil kajian terdahulu dari sumber Litbang Bappeda, Dinas Pekerjaan Umum, PDAM, Dinas Lingkungan Hidup Kota Bontang, dan Pupuk Kaltim 
dan LNG Bontang. Peralatan yang digunakan untuk survai adalah kompas, GPS, flow meter, roll meter, distance meter, dan peta dasar.

\subsection{Pendekatan}

Selainpendekatan kuantitatif, pada penelitian ini dilakukan pula pendekatan kualitatif analitik.Terutama berkaitan dengan kendala pengelolaan dan pengembangan energi terbarukan oleh pemerintah daerah serta kesiapan masyarakatnya. Dimana data-data tersebut akan lebih banyak dikumpulkan dari survei, wawancara dan diskusi langsung. Adapun untuk rekomendasi yang akan diberikan pada penelitian ini dilakukan secara kualitatif.

\subsection{Pengumpulan Data}

Pengumpulan data dimaksudkan untuk kajian analisis menggunakan data sekunder untuk review dokumen hasil studi pernah dilakukan sebelumnya. Selain kajian hasil studi yang pernah ada, juga akan dilakukan survei ke lokasi untuk interview dengan pejabat pemda terkait dan masyarakat, guna melengkapi data yang dibutuhkan.

Data sekunder yang berhasil dikumpulkan, akan dilakukan review dan diskusi internal untuk yakin bahwa data yang diperoleh memiliki validitas yang tinggi dan dapat dipercaya. Data primer yaitu data yang bersumber dari survei atau observasi lapangan, data primer dapat berupa kuesioner hasil wawancara maupun potret kondisi eksisting di lapangan, termasuk hasil pengukuran secara instrumentasi dengan peralatan, misalnya data kedalaman permukaan air tanah. Survey lapangan dilakukan untuk melihat secara langsung dan melakukan pengukuran potensi sumberdaya air, potensi daerah tampungan air, dan kondisi sosial ekonomi masyarakat.

\subsection{Diskusi}

Kegiatan ini dilakukan pada awal pelaksanaan survey. Konsultasi dan diskusi dilakukan dengan pihak pemerintah kotadanbeberapa pihak terkait setempat. Konsultasi dilakukan dengan Pihak Dinas Binamarga dan Sumberdaya Air, Badan Lingkungan Hidup, Dinas Energi dan Sumberdaya Mineral, PDAM Kota Bontang dan PT. Pupuk Kaltim.

\section{HASIL DAN PEMBAHASAN}

\subsection{Iklim Kota Bontang}

Wilayah Kota Bontang termasuk daerah khatulistiwa dan dipengaruhi iklim tropis basah dengan ciri-ciri khas hujan terjadi di sepanjang tahun dengan suhu rata-rata $24^{\circ}-33^{\circ} \mathrm{C}$. Oleh karena itu, hampir tidak memiliki perbedaan pergantian musim hujan dan kemarau. Angin musim Barat pada umumnya terjadi pada bulan November-April dan musim angin timur terjadi pada bulan Mei-Oktober. Curah hujan (>2500 mm/tahun) dipengaruhi oleh bertiupnya angin muson barat yang basah pada bulan Desember-Februari yang menyebabkan hujan, sedangkan pada bulan Juni-September bertiup angin muson timur yang menyebabkan terjadinya kemarau (Anonim 8, 2012)

\subsection{Potensi Curah Hujan}

Potensi Curah Hujan berdasarkan data curah hujan harian selama 29 tahun di Kota Bontang ratarata di atas $100 \mathrm{~mm}$. Curah hujan harian di wilahah Bontang dapat dilihat pada Gambar 1 (Lampiran). Dengan demikian Kota Bontang dapat dikatakan memiliki curah hujan cukup sebagai potensi sumber air. Suhu udara di Kota Bontang bervariasi antara 27 - 27,9 ${ }^{\circ}$ Celcius. Suhu udara ini cukup untuk mendorong terjadinya penguapan air dan kondensasi di Kota Bontang, sehingga terkumpul uap air yang cukup di udara sebagaimodal pembentukan hujan. Sedangkan kelembaban nisbi udararata-rata antara 71 - 77 \%. Kondisi ini mencerminkan tingginya uap air yang terkandung di dalam udara yang rata-rata mencapai 71 - $77 \%$. Bahkan kondisi kelembaban udara dapat mencapai $94 \%$ di beberapa bulan tertentu. Sungai-sungai yang ada di Bontang tidak besar dan daerah tangkapan airnya kecil, oleh karena itu debitnya tidak besar. Curah hujan yang cukup besar mempunyai potensi untuk dikelola airnya, terutama yang jatuh selama muim hujan dan ditampung dalam penampungan (kolam / embung) untuk menambah kebutuhan masyarakat kota dan industri.

Alternatif pengembangan kolam penampungan atau embung di bagian hulu merupakan solusi pemanfaatan yang berdampak ganda, sebagai sumber air langsung dan sebagai sumber resapan bagi pengisian akuifer. Dengan mengatur aliran-aliran sungai yang ada, menghitung potensinya serta kebutuhan jangka panjang, maka ukuran embung dapat disesuaikan, dengan mempertimbangkan resapan dan pengambilan langsung untuk dimanfaatkan. Potensiair permukaan terdapat di 9 (sembilan) Daerah Aliran Sungai (DAS) yang melewati Kawasan Kota Bontang, dapat dilihat pada Tabel 1 (Lampiran). 
Estimasi Debit Daerah Aliran Sungai (DAS), dengan perkiraan rata-rata curah hjan 2,039 $\mathrm{mm} /$ tahun dan nilai koefisien run off (C) rata2 berkisar 0,85\%, maka potensi aliran permukaan pada wilayah DAS di wilayah Kota Bontang digambarkan seperti Tabel 2 (Lampiran).

Berdasarkan Tabel di atas, dengan mempertimbangkan data penggunaan lahan dan koefisien run off, maka di dapatkan nilai potensi run off seperti terlihat pada Tabel di atas, dimana yang terbesar adalah DAS Bontang dengan potensi debit run off 3.281,63 It/detik. Sebagai ilustrasi, potensi debit run off ini, apabila dikelola dengan baik akan mampu untuk menyediakan sumber air bagi 2 juta lebih penduduk.

DAS Terbesar kedua adalah DAS Nyerakat dengan potensi debit run off 1.650,10 liter/detik. DAS Terbesar ketiga adalah DAS Busuk dengan potensi debit run off 1.417,80 liter/detik, dan selanjutnya DAS Guntung dengan potensi debit run off 1,297,66 liter/detik. Potensi debit DAS di wilayah Kota Bontang secara lebih jelas dapat dijelaskan pada Gambar 2.

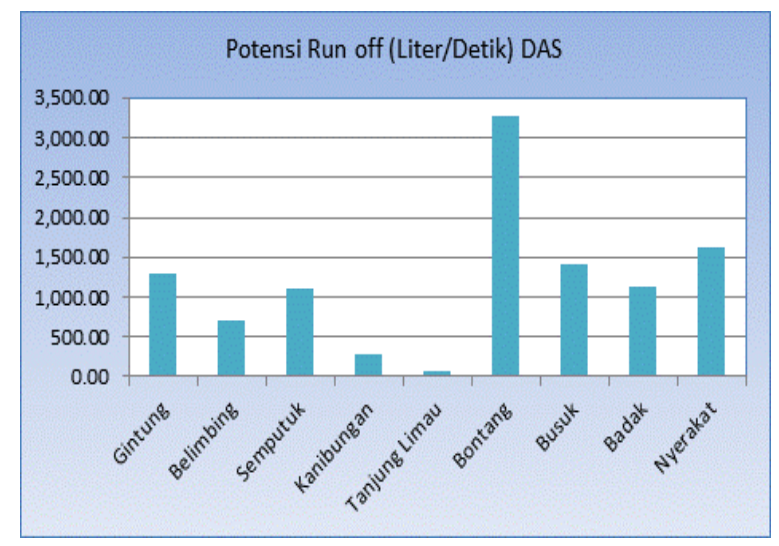

Gambar 2. Potensi debit Run Off DAS di Wilayah Kota Bontang.

Adanya kebutuhan air dalam jumlah besar oleh industri, memaksa pengambilan air tanah dalam jumlah besar, karena keterbatasan sumber air permukaan. Jika industri berkembang terus, maka akan terjadi kekurangan air untuk kebutuhan masyarakat. Optimalisasi pengelolaan sumberdaya air yang ada harus dilakukan sedini mungkin untuk perencanaan pemakaian dan pembangunan dalam jangka panjang serta pengamanan pembangunan dari sisi kebutuhan air.

\subsection{Potensi Air Tanah}

Potensi air tanah Bontang cukup baik, dan wilayah imbuhan terletak pada bagian perbukitan yang tinggi. Daerah yang bagus dan perlu mendapat perhatian sebagai daerah resapan terkait dengan kondisi batuannya, untuk daerah dengan kondisi tanah lempung sebaiknya tetap dipertahankan dalam kondisi hutan yang lebat, karena jika dalam kondisi terbuka akan menghasilkan aliran permukaan yang besar pada saat hujan.

Bontang terdiri atas perbukitan yang secara fisiografi merupakan perbukitan lipatan yang memanjang dari selatan ke utara. Perbukitan dengan ketinggian berkisar 100 sd 300 meter ini tersusun oleh batuan sedimen yang terangkat dengan kemiringan umum menunjam ke timur. Saat ini di wilayah ini banyak terdapat aktivitas penambangan yang banyak membuka hutan dan penggalian secara besar-besaran, sehingga menimbulkan perubahan pada pola resapan dan perubahan kualitas air sungai-sungainya.Kemiringan batuan yang mengarah ke timur sangat menguntungkan, karena imbuhan pada daerah perbukitan akan masuk ke bagian bawah kota Bontang (Gambar 3).

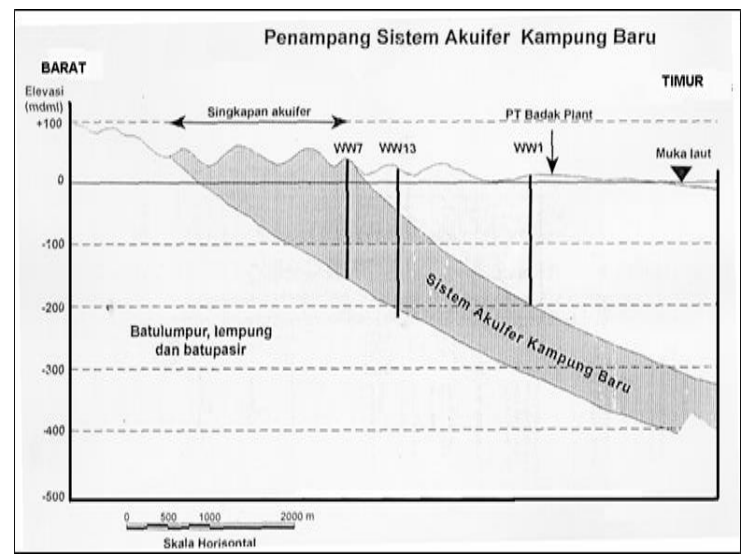

Gambar 3. Penampang Melintang GeologiArah Barat-Timur (Anonim 1,2002 dan LAPI ITB, 2013)

Pemakaian air tanah dalam, akan meningkat tajam sejalan dengan pertumbuhan penduduk, dan diperkirakan kebutuhan air tanah dalam mencapai 2.236 liter/detik pada Tahun 2025. Jika pertumbuhan mengikuti persamaan polynomial maka persamaannya sebagai berikut : $y=23511 x^{2}+$ 17720x; dengan $R^{2}=0,974$, dan jika mengikuti persamaan exponential $y=61021 \mathrm{e}^{0,151 x}$; dengan $R^{2}=$ 0,997, dimana y adalah kebutuhan air (liter/detik) dan $\mathrm{x}$ adalah tahun perkiraan, dan $\mathrm{R}$ adalah simpangan. 
Air yang digunakan untuk keperluan pengambangan air bersih (WTP = Water Treatment Plant) bersumber dari air tanah dalam. Untuk melayani kebutuhan masyarakat, dengan menggunakan formula yang sama, maka peningkatan kapasitas WTP pada Tahun 2025 akan mencapai 1.857 liter/detik.

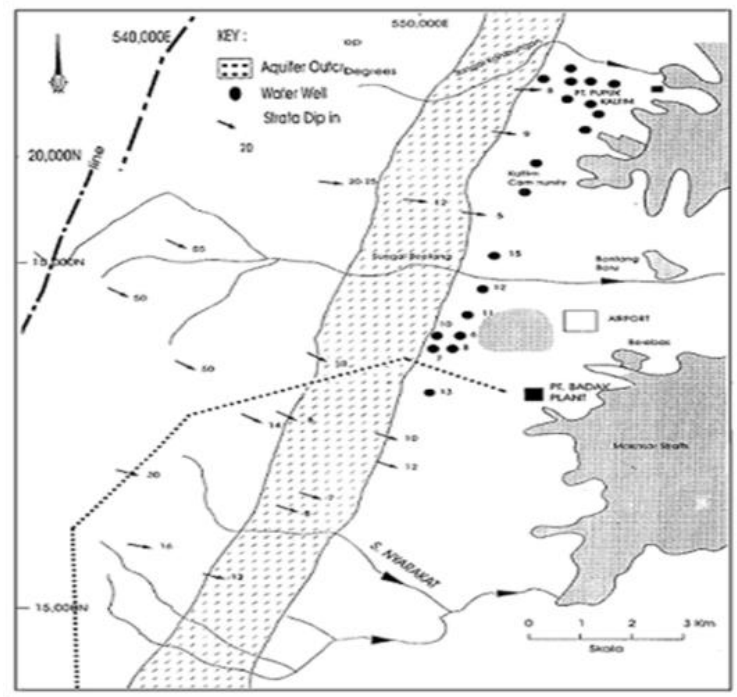

Gambar 4. DAS dan Arah aliran sungai dari barat ke timur melalui akuifer produktif (Anonim 1,2002 dan LAPI ITB, 2013).

\subsection{Sumber Air}

Sumber air Kota Bontang dapat berasal dari air tanah, sungai, dan penampungan air hujan (embung atau waduk). Dalam beberapa dekade terakhir air tanah dijadikan andalan bagi sumber air industri dansebagian masyarakat, sisanya menggunakan air sungai dan air tadah hujan. Dengan curah hujan yang besar, maka pembuatan embung dalam jumlah besar dapat membantu untuk cadangan air pada masa yang akan datang. Saat ini di Kota Bontang tidak ada sumber air sungai yang dapat diolah menjadi air bersih, sehingga hanya mengandalkan air tanah. Air yang bersumber dari air tanah tidak memerlukan penampungan khusus, tetapi langsung disalurkan pada instalasi pengolahan air tanahnya, untuk pengaturan $\mathrm{pH}$ dan penghilangan zat besi dan mangannya.

Bontang terdiri dari 3 kecamatan, yaitu Kecamatan Bontang Barat, Kecamatan Bontang Utara, dan Kecamatan Bontang Selatan. Kecamatan - Kecamatan Bontang terlayani air bersih yang berasal dari PDAM melalui pemipaan. Namun adanya keterbatasan pasokan listrik dari PLN, maka PDAM sering terganggu dalam memproduksi air.
Untuk mengatasi masalah tersebut, dilakukan giliran di tiga kecamatan. Praktis, masyarakat harus menyediakan tempa tpenampungan air, karena PDAM tidak mengalirkan air setiap hari, tapi 3 hari sekali.

Saat ini, pemerintah Kota Bontang, melalui Dinas Pekerjaan Umum sedang menjajaki peluang kerjasama dengan Kutai Kartanegara untuk memanfaatkan Sungai di Marang kayu sebagai sumber air bersih Kota Bontang pada masa yang akan datang. Hal ini dilakukan ,mengingat kawasan Hutan Lindung Bontang sebagai catchmentarea dalam sepuluh tahun terakhir terus dirambah dan hutannya sudah kritis.

\subsection{SumberAirMinum}

Cakupan pelayanan air bersih telah mencapai $71 \%$ dari jumlah penduduk perkotaan. Namun demikian, perlu mendapat perhatian bahwa pelayanan pasokan air bersih kepada konsumen tersebut belum semuanya dapat terlayani selama 24 jam per hari dan kualitas air yang diterima oleh konsumen di beberapa lokasi masih belum memuaskan dan memenuhi persyaratan standar yang diijinkan. Diperkirakan masih terdapat masyarakat miskin di perkotaan yang belum terlayani baik dengan sistem perpipaan maupun sistem non perpipaan yang terlindungi.

Untuk meningkatkan kuantitas air bersih, pemerintah telah memiliki Pembangunan sumur dalam dengan cara bertahap dari tahun ke tahun. Hal ini dilakukan oleh Pemerintah Kota Bontang untuk menyediakan air bersih bagi masyarakat serta untuk menambah cakupan air bersih. Sedangkan untuk meningkatkan kualita sair, pemerintah membangun Instalasi Pengolahan Air (IPA).

Pada tahun 2011 sudah direncanakan akan dibangun 2 IPA baru di wilayah Kecamatan Bontang Selatan dan Bontang Barat. Berdasarkan Laporan Kegiatan Dinas Kesehatan Bontang (2010), bahwa cakupan kualitas bakteriologis air minum yang memenuhi syarat di Kota Bontang juga mengalami kenaikan dari $80 \%$ pada tahun 2009 , naik menjadi 90\% pada tahun 2010.

Pelayanan air bersih kepada masyarakat kota Bontang dilakukan oleh beberapa pihak:

1. Perusahaan Daerah Air Minum (PDAM) Tirta Taman Kota Bontang melakukan pendistribusian dengan dua cara, yaitu; melalui pipa distribusi ke rumah-rumah penduduk. Untuk wilayah tertentu yang belum terlayani dengan jaringan pipa, dan ketika ada gangguan, pendistribusian dilakukan dengan menggunakan mobil tangki. Sedang pelayanan oleh PT. Pupuk Kaltim, Tbk dan PT. Badak NGL 
dapat memenuhi kebutuhan air bersih pada lingkungan perumahan kedua perusahaan masing-masing dan kebutuhan masyarakat di sekitarnya.

2. Pengadaan air bersih yang dilakukan langsung oleh masyarakat dengan usaha air, seperti sumur bor dilakukan dengan dua cara, yaitu dengan melalui pipa langsung ke rumah masyarakat dan dijual menggunakan mobil tangki. Meskipun harga tergolong mahal, namun peminatnya cukup banyak karena pelayanan lancar.

Berdasarkan data di atas diketahui jumlah rumah tangga yang paling banyak terlayani berada di Kecamatan Bontang Utara sebesar 27,64\%, sedang Kecamatan Bontang Barat merupakan daerah yang paling sedikit terlayani PDAM yaitu sebesar 7,51\%. Pada Tingkat Kota Bontang jumlah rumah tangga yang terlayani PDAM mencapai 52,19\%.

\subsection{Analisis Kebutuhan Air}

Analisis kebutuhan prasarana air minum digunakan untuk memprediksi kebutuhan air minum lima tahun ke depan, serta untuk mengetahui gap analisis antara kebutuhan dan ketersediaan pelayanan. Gap analisis di bawah ini mengasumsikan adanya pertumbuhan penduduk Kota Bontang yang setiap tahunnya mengalami peningkatan dengan debit ketersediaan adalah debit produksi PDAM sebesar $330 \mathrm{lt} /$ det. Dari gap analisis berikut terlihat bahwa kebutuhan air minum yang meningkat tiap tahun hingga tahun 2013 masih bisa dipenuhi oleh ketersediaan air minum dari PDAM meskipun tiap tahun kapasitas ketersediaan menurun. Namun demikian hal tersebut perlu diantisipasi agar kapasitas ketersediaan tetap terjaga untuk mengatasi pemenuhan kebutuhan yang terjadi setelah tahun 2013.

Berdasarkan Gambar5, jumlah penduduk Kota Bontang akan terus mengalami peningkatan. Pada tahun 2011 jumlah penduduk di Kota Bontang sekitar 180.000 jiwa kemudian tahun 2025 diperkirakan jumlah penduduk Kota Bontang akan mencapai hampir 400.000 jiwa. Kebutuhan air Kota Bontang saat ini mencapai 250 liter/detik dan terus meningkat pada tahun 2025 akan mencapai hampir 500 liter/detik. Di Kota Bontang ada dua industri besar, yaitu PT Pupuk Kaltim dan PT Badak NGL yang membutuhkan air cukup besar, walaupun saat ini keduanya banyak bergantung pada air tanah dalam.Pada Tahun 2025 kebutuhan air industri sulit diprediksi, oleh karena itu diamsumsikan untuk industri kebutuhan airnya mencapai 1.000 liter/detik.

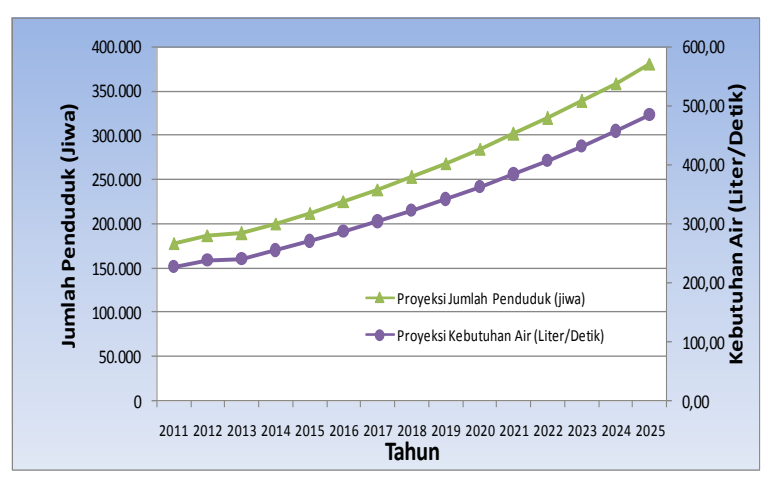

Gambar 5. Proyeksi Jumlah Penduduk Dan Kebutuhan Air Kota Bontang.

Dengan demikian kebutuhan air Kota Bontang, baik untuk domestik dan Industri pada Tahun 2025 akan mencapai 1.500 liter/detik. Sejalan dengan itu rencana pengembangan PDAM pun harus mengikuti, dimana air terjual dan sampai ke konsumen harus menyesuaikan. Jika dilihat dari pengalaman beberapa tahun terakhir maka, ketersediaan air baku akan lebih besar dari air yang terjual dan berdasarkan rasio yang ada diperkira-kan kebutuhan air baku pada Tahun 2025 akan mencapai 2.518 liter/detik.

Perencanaan penyediaan air baku perlu direncanakan dari sekarang, walaupun kondisi air tanah masih bagus, nampaknya perlu antisipasi terhadap kerusakan air tanah akibat pemakaian yang berlebihan, dan adanya kecenderungan rusaknya wilayah resapan air. Air permukaan selama ini belum dimanfaatkan secara optimal, disisi lain banjir masih sering terjadi di beberapa tempat dan masih banyak air yang terbuang ke laut selama musim penghujan. Perencanaan pemanfaatan air permukaan perlu dilakukan sedini mungkin, agar ketersediaan lahan dapat dipersiapkan dan tidak banyak gejolak sosial pada saat realisasi pembangunan-nya.

\subsection{PermasalahanAirBersih}

Hasil kajian dalam Strategi Sanitasi Kota Bontang(Disarikan dari Anonim 10, 2011), menyatakan antara lain permasalahan air bersih di Kota Bontang adalah :

- Pelayanan air bersihbaru mencapai cakupan 52,19\%.

- PDAM Kekurangan airbaku.

- Supply daya listrik untuk PDAM masih Kurang.

- Distribusi air tidak merata, tingkat kebocoran hingga $18,55 \%$ dan cakupan pelayanan mencapai $61 \%$.

- SDM kurang optimal dan Sistem pengaduan 
yang belum optimal serta kurangnya dukungan sistem informasi dan lemahnya penegakkan aturan.

- Sulitnya penyesuaian tarif, biaya yang mahal.

- Kelembagaan kurang optimal dan kurangnya dukungan kelembagaan dalam menjalin kemitraan.

\subsection{Proyeksi Produksi Air dan Harga Air}

Proses pengembangan teknologi pengolahan air sangat diperlukan untuk peningkatan efisiensi dalam penggunaan air baku dan menurunkan kebocoran pada sistem. Proyeksi Produksi Air dilakukan dengan asumsi tidak ada pengembangan teknologi proses pengolahan air. Dengan asumsi tersebut, maka untuk pemenuhan kebutuhan air bersih Kota Bontang pada Tahun 2025 memerlukan jumlah air produksi sebesar 1.678 liter/detik. Namun demikian tidak semua air terproduksi dapat sampai ke konsumen, kehilangan air selama proses distribusi bisa terjadi akibat kebocoran pipa dalam perjalanan dari instalasi menuju konsumen (Gambar 6-Lampiran).

Dengan asumsi kondisi tidak banyak berubah, maka jumlah air yang terdistribusi pada Tahun 2025 mencapai 1.598 liter/detik.Proyeksi air terjual sejalan dengan peningkatan kebutuhan air domestik, maka pada Tahun 2025 akan mencapai 1.332 liter/detik. Untuk Perencanaan harus difikirkan juga kebutuhan air untuk industri, yang diperkirakan akan membutuhkan air sebanyak 1.000 liter/detik. Salah satu pertimbangan untuk melakukan investasi adalah menentukan prediksi harga air kedepan. Jika dilihat dari perkembangan harga air dari tahun 2004 sampai dengan 2011, maka harga air akan cenderung meningkat dari tahun ke tahun dan diperkirakan akan mencapai $10,000 \mathrm{Rp} / \mathrm{m}^{3}$ pada tahun 2015 (Gambar 7Lampiran).

\subsection{Pengembangan Sumber Air Baku}

Dari 9 (sembilan) DAS yang ada di Bontang ada 4 (empat) DAS yang memungkinkan dikembangkan untuk dibangun penampungan air sebagai persediaan musim kemarau dan pengendali banjir.

\subsubsection{DAS Bontang}

Sungai Bontang membentang dari Kelurahan Bontang Kuala, Api-api, Kanaan, Gunung Elai, dan Gunung Telihan. Sungai Bontang melayani kawasan di Kelurahan Bontang Kuala, Bontang Baru, Api-api,
Kanaan, Gunung Elai, dan Gunung Telihan dan sekitarnya. Luas DAS 5.971 ha, panjang aliran sungai sepanjang 25,62km. Lebar sungai antara 4-10 meter dengan kedalaman rata-rata 1-2,5 meter. Ketinggian air pada saat surut terendah adalah 1 meter, sedangkan ketinggian air pada saat pasang tertinggi adalah 3,5 meter. Potensi air permukaan sebesar $103.486 .387 \mathrm{~m}^{3} /$ tahun atau $3.281,53$ liter/detik.

Sungai mempunyai wilayah DAS yang meluas sampai dengan wilayah barat di Kutai Timur yang posisinya lebih tinggi dibanding Kota Bontang. Sungai ini dalam beberapa tahun terakhir berpotensi sebagai sumber banjir bagi kota Bontang. Pada musim hujan sungai ini airnya sering meluap membanjiri wilayah di kanan dan kirinya. Jika dimanfaat sebagai sumber air minum, karena fluktuasi debit yang cukup besar, maka diperlukan semacam kolam atau danau penampung air yang berfungsi sebagai kolam pengendali banjir dan sebagai cadangan sumber air bersih bagi masyarakat. Dari potensi yang ada diasumsikan $20 \%$ dari potensinya dapat dikelola sebagai sumber air bersih, dengan demikian potensi air yang bisa dikelola sebagai sumber air sekitar 20.697.276 $\mathrm{m}^{3} /$ tahun

Jika dari potensi air yang dikelola $50 \%$ dimanfaatkan untuk air minum, maka diperlukan unit pengolah air dengan kapasitas sekitar 10,348,638 $\mathrm{m}^{3} /$ tahun atau 328,15 l/detik. Jika kebutuhan air bersih untuk satu orang 110 l/orang/hari, maka jumlah penduduk yang akan mendapat pelayanan dapat bertambah sebanyak 255.390 orang.

\subsubsection{DAS Nyerakat}

Sungai Nyerakat terletak di Kelurahan Bontang Lestari, merupakan kelurahan paling selatan di Kota Bontang. Sungai Nyerakat melayani kawasan di Kelurahan Bontang Lestari dan sekitarnya. Luas DAS Nyerakat kurang lebih 2.938 ha dengan panjang aliran sungai sepanjang $13 \mathrm{~km}$, lebar sungai antara 3-10 meter dengan kedalaman ratarata 1-2 meter. Potensi air permukaan sebesar 50.933.812 $\mathrm{m}^{3} /$ tahun atau 1.615,10 liter/detik. Sungai Nyarekat mempunyai wilayah DAS yang luasnya setengah dari luas DAS Bontang. Sungai ini dalam beberapa tahun terakhir berpotensi sebagai sumber banjir bagi kota Bontang. Pada musim hujan sungai ini airnya sering meluap membanjiri wilayah di kanan dan kirinya. Jika dimanfaat sebagai sumber air minum, karena fluktuasi debit yang cukup besar, maka diperlukan semacam kolam atau danau penampung air yang berfungsi sebagai kolam pengendali banjir dan sebagai cadangan sumber air 
bersih bagi masyarakat. Dari potensi yang ada diasumsikan $20 \%$ dari potensinya dapat dikelola sebagai sumber air bersih, dengan demikian potensi air yang bisa dikelola sebagai sumber air sekitar $10.186,762 \mathrm{~m}^{3} /$ tahun.

Jika dari potensi air yang dikelola $50 \%$ dimanfaatkan untuk air minum, makan diperlukan unit pengolah air dengan kapasitas sekitar 5.93.381 $\mathrm{m}^{3} /$ tahun atau 161,51 l/detik. Jika kebutuhan air bersih untuk satu orang 110 l/orang/hari, maka jumlah penduduk yang akan mendapat pelayanan dapat bertambah sebanyak 126.858 orang.

\subsubsection{DAS Busuk}

DAS Busuk dengan luas $22,78 \mathrm{~km}^{2}$, Sungai mempunyai wilayah DAS yang lebih kecil dibandingkan dengan DAS Bontang meluas sampai dengan wilayah barat yang posisinya lebih tinggi. Sungai ini dalam beberapa tahun terakhir berpotensi sebagai sumber banjir bagi kota Bontang. Pada musim hujan sungai ini airnya sering meluap membanjiri wilayah di kanan dan kirinya. Jika dimanfaat sebagai sumber air minum, karena fluktuasi debit yang cukup besar, maka diperlukan semacam kolam atau danau penampung air yang berfungsi sebagai kolam pengendali banjir dan sebagai cadangan sumber air bersih bagi masyarakat. Potensi air permukaan sebesar $44.771 .804 \mathrm{~m}^{3} /$ tahun atau $1.417,8$ liter/detik. Sungai mempunyai wilayah DAS yang lebih kecil. Jika dimanfaat sebagai sumber air minum, karena fluktuasi debit yang cukup besar, maka diperlukan semacam kolam atau danau penampung air yang berfungsi sebagai kolam pengendali banjir dan sebagai cadangan sumber air bersih bagi masyarakat. Dari potensi yang ada diasumkan $20 \%$ dari potensinya dapat dikelola sebagai sumber air bersih, dengan demikian potensi air yang bisa dikelola sebagai sumber air sekitar 8.954.360 $\mathrm{m}^{3} /$ tahun.

Jika dari potensi air yang dikelola 50\% dimanfaatkan untuk air minum, makan diperlukan unit pengolah air dengan kapasitas sekitar 4.477.180 $\mathrm{m}^{3} /$ tahun atau 141,97 l/detik. Jika kebutuhan air bersih untuk satu orang 110 l/orang/hari, maka jumlah penduduk yang akan mendapat pelayanan dapat bertambah sebanyak 111.511 orang.

\subsubsection{DAS Gintung.}

Sungai Guntung terletak di Kelurahan Guntung merupakan kelurahan paling Utara di Kota Bontang. Sungai Guntung melayani kawasan di Kelurahan Guntung dan sekitarnya. Luas DAS
Guntung kurang lebih 2.361 ha dengan panjang aliran sungai sepanjang $11,36 \mathrm{~km}$. Lebar sungai antara 2-10 meter dengan kedalaman rata-rata 1-2 meter. Ketinggian air pada saat surut terendah adalah 1 meter, sedangkan ketinggian air pada saat pasang tertinggi adalah 3,5 meter. Potensi air permukaan sebesar $40.923 .138 \mathrm{~m}^{3} /$ tahun atau 1.297 liter/detik. Sungai mempunyai wilayah DAS yang kurang luas dibandingkan dengan DAS Bontang meluas sampai dengan wilayah barat yang posisinya lebih tinggi. Sungai ini dalam beberapa tahun terakhir berpotensi sebagai sumber banjir bagi kota Bontang.

Pada musim hujan sungai ini airnya sering meluap membanjiri wilayah di kanan dan kirinya. Jika dimanfaat sebagai sumber air minum, karena fluktuasi debit yang cukup besar, maka diperlukan semacam kolam atau danau penampung air yang berfungsi sebagai kolam pengendali banjir dan sebagai cadangan sumber air bersih bagi masyarakat. Dari potensi yang ada diasumkan $20 \%$ dari potensinya dapat dikelola sebagai sumber air bersih, dengan demikian potensi air yang bisa dikelola sebagai sumber air sekitar 8.184.627 $\mathrm{m}^{3} /$ tahun.

Jika dari potensi air yang dikelola 50\% dimanfaatkan untuk air minum, makan diperlukan unit pengolah air dengan kapasitas sekitar 4.092.313 $\mathrm{m}^{3}$ /tahun atau $129,76 \mathrm{l} /$ detik. Jika kebutuhan air bersih untuk satu orang $110 \mathrm{l} /$ orang/hari, maka jumlah penduduk yang 101.925 orang. Keempat DAS tersebut merupakan bagian dari Sub DAS Santan Ilir yang semuanya bermuara di Selat Makassar. Sungaisungai tersebut juga mengalirkan air yang berasal dari mata air, terutama air yang keluar dari batuan pasir halus, pasir kasar dan lempung pasiran yang berasal dari formasi Balikpapan.

\subsection{Air Untuk Industri}

Ada dua Industri utama yang ada di Kota Bontang, yaitu Industri PT. Pupuk Kaltim dan LNG Badak, saat ini kedua industri tersebut masih mengandalkan air bersihnya dari air tanah dalam. PT Pupuk Kaltim berencana meningkatkan produksinya, sehingga konsumsi kebutuhan air bersihnya akan bertambah $800 \mathrm{l} /$ detik. Alternatif penambahan sumber air diperlukan untuk menunjang beroperasinya rencana pengembangan industrinya kedepan.

Total Potensiair permukaan yang dapat dijadikan air permukaan, dengan asumsi pemanfaatan sumberdaya hanya 20\% (ditampung dalam waduk) dan dari dalam waduk tersebut dapat dimanfanfaatkan hanya $50 \%$, maka total potensi air 
bersih yang dapat dioptimalkan dari sumber air permukaan adalah sebesar $761.14 \mathrm{l} /$ detik.

Pupuk Kalimantan Timur (PKT) dalam rangka pengembangannya membutuhkan tambahan air bersih berkapasitas $1000 \mathrm{~m}^{3} / \mathrm{jam}$ atau $(166,67$ liter/detik) dengan spesifikasi air industri untuk kepentingan operasional 3 (tiga) Pabrik pengembangan PKT di tahun 2016. Dari jumlah itu $800 \mathrm{~m}^{3} / \mathrm{jam}$ akan digunakan untuk mensuplai kebutuhan PKT dan $200 \mathrm{~m}^{3} / \mathrm{jam}$ akan digunakan untuk mensuplai kebutuhan PDAM yang setara untuk melayani kebutuhan air untuk 21.818jiwa.

Asumsi penambahan kebutuhan air bersih untuk pengembangan PT PKT sebesar $800 \mathrm{l} /$ detik akan bisa terpenuhi dengan menambah volume bangunan penangkap airnya atau meningkatkan persentase sumberdaya air yang dikelola untuk air bersih.Permasalahan lain adalah masalah jarak dari sumber air ke lokasi pelayanan. Lokasi PT PKT yang dibelah utara Kota Bontang, lebih dekat pada Sungai Bontang dan Sungai Gintung.Potensi yang dapat diambil dari kedua sungai tersebut hanya mencapai 458 l/detik.Oleh karena pemanfaatam dari waduk penampungan harus ditingkatkan dari $50 \%$ menjadi $75 \%$, dengan demikian air yang dapat dimanfaatkan dari kedua sungai tersebut dapat mencapai 686,9 I/detik.

Dalam jangka pendek untuk pemenuhan $1000 \mathrm{l} /$ detik air bersih, harus ditambah sumbernya dari air tanah, sebesar $315 \mathrm{l} /$ detik. Jika satu sumur dalam dapat memasok $15 \mathrm{l} /$ detik, maka dibutuhkan penambahan sumber air dari 21 sumur dalam.Dalam jangka pendek kekurangan bisa diambil dari air tanah dalam (250 - 300 meter dml), karena dari hasil monitoring permukaan air tanah masih belum menunjukkan penurunan permukaan air tanah yang berarti.

Lokasi sumur sebaiknya sekitar wilayah PT PKT sebelah barat dan selatan dan tidak berdekatan dengan sumur-sumur milik PDAM.Untuk memastikan kepasitas sumur sebaiknya pelajari kembali data-data uji pemompaan yang pernah dilakukan dan pengamatan pada hasil monitoring tinggi permukaan air tanah dalam beberapa tahun terakhir.

Dengan pemanfaatan Sungai Bontang, Sungai Gintung dan pemanfaatakan air tanah dalam, maka total potensi yang dibutuhkan sebesar 1000 l/detik bisa dicapai. Untuk itu pencapaian kapasitas tersebut ada beberapa infrastruktur yang harus disiapkan; antara lain :

1) Bangunan penangkap air dan waduk penampungan untuk air dari Sungai Bontang. Bangunan penangkap air sudah sudah ada, namun masih perlu dimodifikasi terkait dengan penangkapan lumpur dan pengaturan pintu airnya. Waduk perlu dilakukan pengerukan dan pendalaman agar daya tampungnya menjadi lebih besar. Drainase sebelilingnya harus diperbaiki, agar erosi dari wilayah sekitarnya tidak masuk kedalam waduk dan mempercepat pendangkalan. Perlu dibangunan Unit pengolahan air bersih kapasitas $2 \times 250 \mathrm{l} /$ detik dan pipa distribusi sejauh $5-6 \mathrm{~km}$.

2) Bangunan penangkap air dan waduk penampungan untuk air dari Sungai Gintung. Pada lokasi ini belum ada bangunan penangkap air dan waduk penampung air. Perlu dibangunan Unit pengolahan air bersih kapasitas 2 × 100 l/detik dan pipa distribusi sejauh $2 \mathrm{~km}$.

3) Sumur dalam sebanyak 21 buah, kedalaman 250 - 300 meter, dengan kapasitas rata-rata 15 I/detik dan pipa distribusinya, serta Instalasi Pengolahan Air Tanah dengan kapasitas 2 x 150 I/detik.

\subsection{Pengembangan Waduk Kanaan}

Pemenuhan kebutuhan air Industri 1000 l/detik, memerlukan lokasi penampungan air baku.Lokasi penampungan air baku yang paling memungkinkan karena letak geografis, ketersediaan lahan dan ketersediaan sumberdaya air adalah Waduk Kanaan. Saat ini Waduk Kanaan difungsikan sebagai waduk pengendali banjir dan akan dilakukan normalisasi. Rencana normalisasi tersebut perlu segera direalisasikan. Namun demikian kondisi existing perlu dikembangkan agar dapat difungsikan juga sebagai penampung air baku guna menunjang kebutuhan air bersih. Dari gambar rencana desain yang ada, Waduk Kanaan mampu menampung air sejumlah $331.000 \mathrm{~m}^{3}$ dengan kedalaman air 4 meter dan luas penampang waduk 8,275 Ha. Lokasi kedua adalah dekat dengan PT PKT, untuk menangkap air dari Sungai Gintung, terutama yang dibagian barat dan tidak terpengaruh oleh pasang-surut air laut.

Rencana embung yang paling mungkin untuk dikembangkan sebagai sumber air baku Kota Bontang adalah Embung Kanaan atau biasa disebut Waduk Kanaan, dengan pertimbangan sebagai berikut:

1) Waduk Kanaan mempunyai posisi yang strategis dekat dengan pusat kota.

2) Waduk Kanaan berada di area DAS yang cukup potensial yaitu DAS Bontang

3) Waduk Kanaan berada di topografi yang relatif tinggi, sehingga memungkinkan untuk air yang ada dapat didistribusikan secara gravitasi ke pusat kota Bontang 
4) Masih terdapat lahan kosong di seputar waduk yang dapat digunakan sebagai tempat pembuatan Instalasi Pengolahan Air (IPA).

Meskipun demikian, dari hasil pengamatan di lapangan ada kendala yang harus diselesaikan terkait pemanfaatan Waduk Kanaan sebagai sumber air baku yaitu:

1) Hulu DAS Bontang terletak di Kabupaten Kutai Timur, sehingga ini memerlukan koordinasi lintas wilayah terkait pengendalian DAS Bontang di daerah hulu.

2) Di bagian atas hulu Danau Kanaan, terdapat pertambangan liar yang berakibat langsung pada meningkatnya sedimentasi di danau.

3) Terdapat area Kuburan Toraja di atas kawasan danau tersebut, yang memerlukan penanganan sistem drainase khusus.

Terkait pengelolaan daerah hulu DAS Bontang, Pemerintah Kota Bontang dapat melakukan koordinasi lintas kabupaten dengan bantuan Pemerintah Propinsi Kalimantan Timur. Dengan demikian koordinasi dapat dijalankan dengan lebih baik, dan terstruktur, dan harapannya bagaimana supaya DAS Bontang dapat dikembangkan menjadi DAS yang sehat, sehingga keberadaan sumberdaya air yang ada dapat dijaga keberlanjutannya.

Dari Gambar 8 (Lampiran), terlihat kondisi Waduk Kanaan saat ini. Luasan waduk saat ini dibatasi oleh garis merah, dan luasan genangan yang ada digambarkan dalam poligon warna kuning. Di sebelah utara waduk terlihat bangunan pengendali banjir. Di sebelah barat terlihat okupasi lahan akibat tambang rakyat ilegal. Jika dibiarkan, okupasi lahan ini akan semakin meluas dan akan menyebabkan sedimentasi tidak terkendali yang akan membahayakan keberadaan Waduk Kanaan. Terdapat juga Kuburan Toraja yang ada di area dekat waduk. Terkait Kuburan Toraja ini, beberapa masyarakat memper-masalahkan leached yang dikawatirkan akan masuk ke waduk dan bercampur dengan genangan yang ada. Di Bulan Januari ketinggian muka air Sungai Bontang dapat mencapai 10 - 12 meter, yang menunjukkan adanya fenomena debit puncak (banjir) di lokasi tersebut.

\subsection{IPA Tambahan}

Rekomendasi lokasi letak IPA adalah di sebelah timur laut dari lokasi waduk Kanaan dengan luas lahan yang dibutuhkan sekitar 60 meter x 150 meter sebagai lokasi unit pengolahanair bersih dengan kapasitas terpasang 2 × 250 liter/detik dan di barat PT PKT sebesar $2 \times 100$ l/detik, dibutuhkan lahan sekitar 25 meter x 50 meter. Untuk Instalasi Pengolahan Air Tanah sebaiknya dekat dengan lokasi pengolahan yang di Sungai Gintung, agar menghemat jumlah tenaga dan kantor kerja.

Jalur distribusi dari instalasi air akan didistribusikan ke Pupuk Kaltim melalui jalan kampung di sebelah timur laut waduk terus ke arah jalan utama Bontang menembus ke arah wilayah Pupuk Kaltim sejauh $6 \mathrm{Km}$ dengan debit $2 \times 250$ liter /detik. Penyambungan ke PDAM Kota Bontang dapat dilakukan pada jaringan pipa di jalan utama (Gambar 9-Lampiran).

\subsection{Daur Ulang Air}

Air hujan yang mengalir sebagai air permukaan mengalir dari pegunungan menuju pantai.Selama ini air tawar banyak terbuang ke laut, padahal sudah banyak diketahui awam bahwa untuk mengolah air laut menjadi air minum cukup mahal. Demikian juga air yang habis digunakan untuk mandi dan cuci, selama ini dibuang ke laut tanpa pengolahan. Sebagai kota yang sedang berkembang, Kota Bontang perlu dipersiapkan dengan kolam penampungan air tawar yang berasal dari drainase kota. Potensi airnya sekitar $80 \%$ dari air yang digunakan untuk keperluan domestik, ditambah industri, yang dapat di daur ulang untuk penggunaan lain, yang tidak membutuhan kualifikasi yang tinggi seperti air minum. Pada masa mendatang kebutuhan air untuk industri dan domestic dapat mencapai $1500 \mathrm{l} /$ detik, ini artinya akan ada potensi air sebesar $1200 \mathrm{l} /$ detik (80\%) untuk didaur ulang.

Secara desain, jumlah air yang di daur ulang minimal 1200 liter/detik (belum termasuk air hujan). Untuk menunjang Kota Bontang sebagai kotaindustri, air akan menjadi kebutuhan utama dan harus dipersiapkan secara matang. Jika kebutuhan air 1500 liter/detik, maka persiapkan cadangan airnya dua kalinya, karena tidak mungkin untuk memanfaatkan seluruh cadangan air untuk diproses menjadi air bersih, maksimal 50\% dari cadangan yang tersedia. Dengan pertimbangan itu, maka desain kolam cadangan air untuk daur ulang air harus di desain dengan 3000 l/detik (259.200 $\mathrm{m}^{3} /$ hari). Untuk kapasitas sebesar itu membutuhkan kolam penampungan dengan volume $259.200 \mathrm{~m}^{3}$, dengan kedalaman 2 meter, akan membutuhkan luasan sekitar $129.600 \mathrm{~m}^{2}$ (13 ha). Kawasan ini terbagi dalam tiga kompartmen, pertama 7,8 ha, kedua 2,6 ha dan ketiga 2,6 ha. Proses daur ulang dilakukan pada compartment ketiga. Air mengalir dari kompartmen pertama menuju ketiga. Lokasi yang dipilih dekat pantai, secara grafitasi air masih mengalir dan tidak terpengaruh oleh pasang surut air laut. 


\section{KESIMPULAN DAN SARAN}

- DAS Bontang mempunyai potensi aliran permukaan terbesar, yaitu 3.281,63 It/detik.

- Waduk Kanaan dapat difungsikan sebagai penahan banjir dan penyimpan air baku. Instalasi saat ini baru bisa difungsikan sebagai instalasi penahan banjir. Untuk fungsi penyimpan air baku perlu dilakukan perbaikan infrastruktur. Kapasitas waduk Kanaan dengan luas 8,275 hektar pada kedalaman air 4 meter berpotensi untuk menyimpan 331 juta $\mathrm{m}^{3}$. Kondisi instalasi pengendali air saat ini belum berfungsi optimal.

- Potensi air waduk Kanaan dapat digunakan untuk memasok air IPA.Lokasi IPA yang memungkinkan adalah di timur laut Waduk Kanaan dengan kapasitas $2 \times 250 \mathrm{l} /$ detik.

- Dalam jangka pendek penggunaan air tanah masih dibutuhkan untuk menjunjang kebutuhan air $1000 \mathrm{l} /$ detik. Potensi yang dapat dimanfaatkan dari Sungai Bontang dan Sungai Gintung hanya $686.9 \mathrm{l} /$ detik, oleh karena itu kekurangan $315 \mathrm{l} /$ detik akan di supply dari air tanah dalam (250-300m).

- Potensi daur ulang bisa dimanfaatkan dalam masa mendatang, namun perlu membangun infrastruktur untuk penampungan air dari hasil drainase kota dan air hujan. Lokasi yang tepat untuk membangun penampungan air dari kota adalah dekat pantai, namun belum terpengaruh oleh pasang surut air laut.

\section{DAFTAR PUSTAKA}

- $\quad$ Anonim1, 2002, Amdal RKL RPL LNG Bontang.

- Anonim 2, 2005, Studi Penanggulangan Banjir dan Penyusunan DED Kota Bontang, PT Indra Karya, Consultant Engineers.

- Anonim 3, 2007, Bontang Dalam Angka, Kerjasama Bappeda dan BPS

- Anonim 4 2008, Bontang Dalam Angka, Kerjasama Bappeda dan BPS

- Anonim 5, 2009, Bontang Dalam Angka, Kerjasama Bappeda dan BPS

- Anonim 6, 2010, Bontang Dalam Angka, Kerjasama Bappeda dan BPS

- Anonim 7, 2011, Bontang Dalam Angka, Kerjasama Bappeda dan BPS

- Anonim 8, 2012, Bontang Dalam Angka, Kerjasama Bappeda dan BPS

- Anonim 9, 2012, Data Monitoring Sungai Bontang, DPU Provinsi, Samarinda (Digital).

- $\quad$ Anonim 10, 2011, Strategi Sanitasi Kota (SSK)
Kota Bontang .

- Anonim11, 2011, Profil Kependudukan Kota Bontang Tahun 2011. Dinas Kependudukan dan Pencatatan Sipil Kota Bontang.

- Anonim12, 2012, Millenium Development Goals, United Nations Organization.

- Anonim13, 2013, Data-Data Sumberdaya Air untuk PT PKT (digital).

- Anonim14, 2013, Data-Data Operasional dan Produksi PDAM Kota Bontang (digital).

- Anonim15, 2013, Dokumen Perencanaan Normalisasi Waduk Kanaan, Dinas PU Provinsi (digital)

- Arie Herlambang, Joko Widodo, M. Abdul Kholiq, Budi. H.S., 2013, Studi Evaluasi Potensi Sumberdaya Air Kota Bontang, BTL, BPPT.

- LAPI ITB, 2013, Laporan Antara Kajian Ketersediaan Air tanah Kegiatan Peningkatan Konservasi Daerah Tangkapan Air dan Sumber-Sumber Air.

- $\quad$ POKJA AMPL, 2011, Buku Putih Sanitasi Kota Bontang. 




Gambar 1. Curah Hujan Harian Sungai Bontang (Anonim09, 2012)

Tabel 1. DAS Kota Bontang (Anonim 3-8, 2012)

\begin{tabular}{|c|l|c|c|c|}
\hline No & \multicolumn{1}{|c|}{ Nama DAS } & Luas DAS (km2) & $\begin{array}{c}\text { Panjang Sungai } \\
(\mathbf{K m})\end{array}$ & Keterangan \\
\hline 1 & Guntung & 23,612 & 15,879 & $86,37 \%$ wilayah Kutim \\
\hline 2 & Belimbing & 15,627 & 11,300 & \\
\hline 3 & Semputuk & 20,002 & 20,590 & $86,11 \%$ wilayah Kutim \\
\hline 4 & Kanibungan & 5,190 & 4,892 & $92,70 \%$ wilayah Kutim \\
\hline 5 & Tjg Limau & 1,478 & 3,480 & \\
\hline 6 & Bontang & 59,710 & 41,179 & \\
\hline 7 & Busuk & 25,798 & 11,010 & \\
\hline 8 & Badak & 20,468 & 9,650 & \\
\hline 9 & Nyerakat & 29,388 & 22,295 & \\
\hline
\end{tabular}

Tabel 2. Potensi Aliran Permukaan.

\begin{tabular}{|c|l|c|c|c|}
\hline No & \multicolumn{1}{|c|}{ DAS } & LUAS & \multicolumn{2}{c|}{ Aliran Permukaan } \\
\hline & & $\mathbf{( m}^{\mathbf{2}} \mathbf{l}$ & ( $^{\mathbf{3}} /$ Tahun) & (It/detik) \\
\hline 1 & Guntung & 23.612 .000 & 40.923 .138 & $1.297,66$ \\
\hline 2 & Belimbing & 12.627 .000 & 21.884 .485 & 693,95 \\
\hline 3 & Semputuk & 20.002 .000 & 34.666 .466 & $1.099,27$ \\
\hline 4 & Kanibungan & 5.190 .000 & 8.995 .049 & 285,23 \\
\hline 5 & Tjg Limau & 1.478 .000 & 2.561 .596 & 81,23 \\
\hline 6 & Bontang & 59.710 .000 & 103.486 .387 & $3.281,53$ \\
\hline 7 & Busuk & 25.798 .000 & 44.711 .804 & $1.417,80$ \\
\hline 8 & Badak & 20.468 .000 & 35.474 .114 & $1.124,88$ \\
\hline 9 & Nyerakat & 29.388 .000 & 50.933 .812 & $1.615,10$ \\
\hline
\end{tabular}




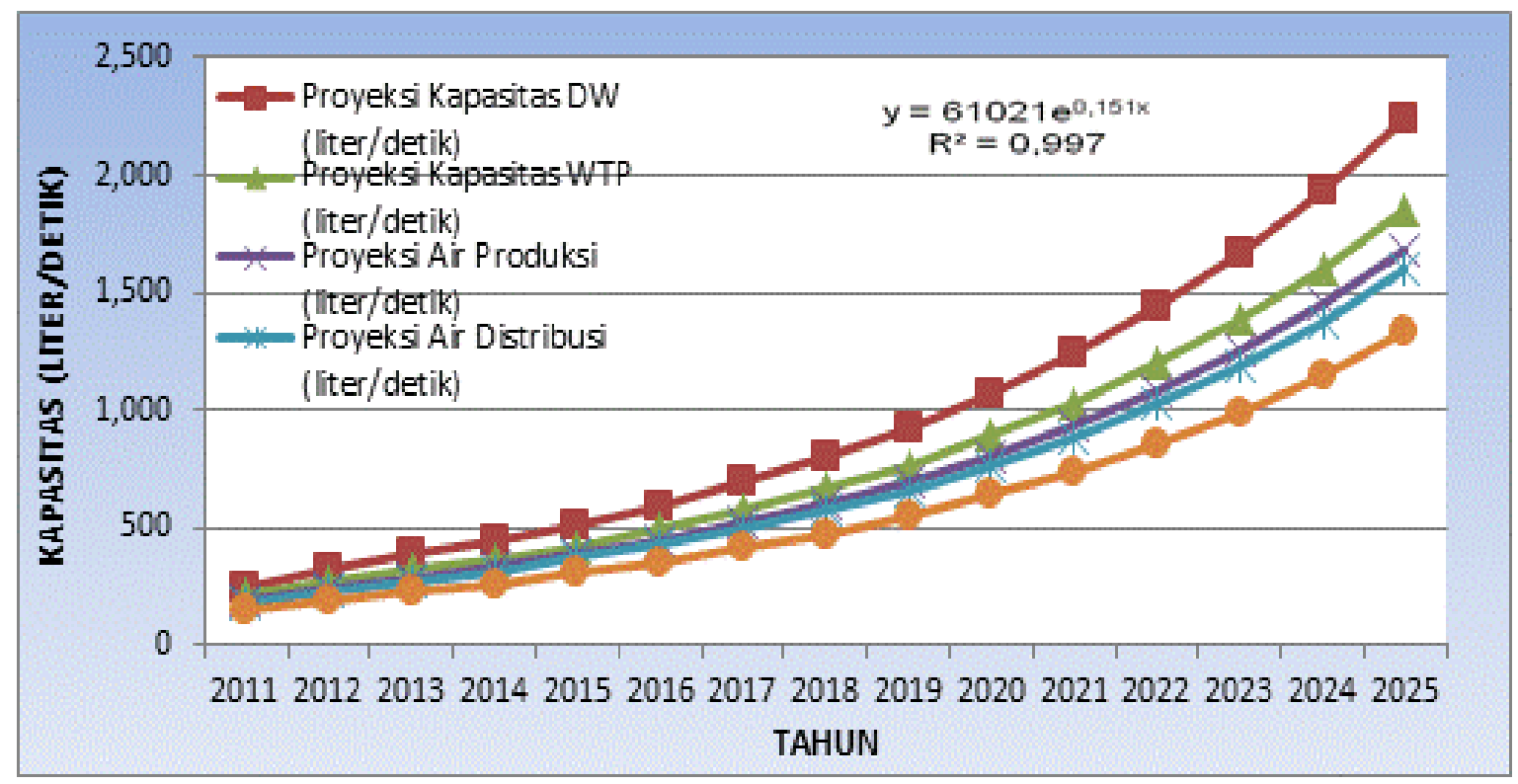

Gambar 6. Proyeksi Kapasitas dan Distribusi PDAM (Analisis dari Anonim 14, 2013)

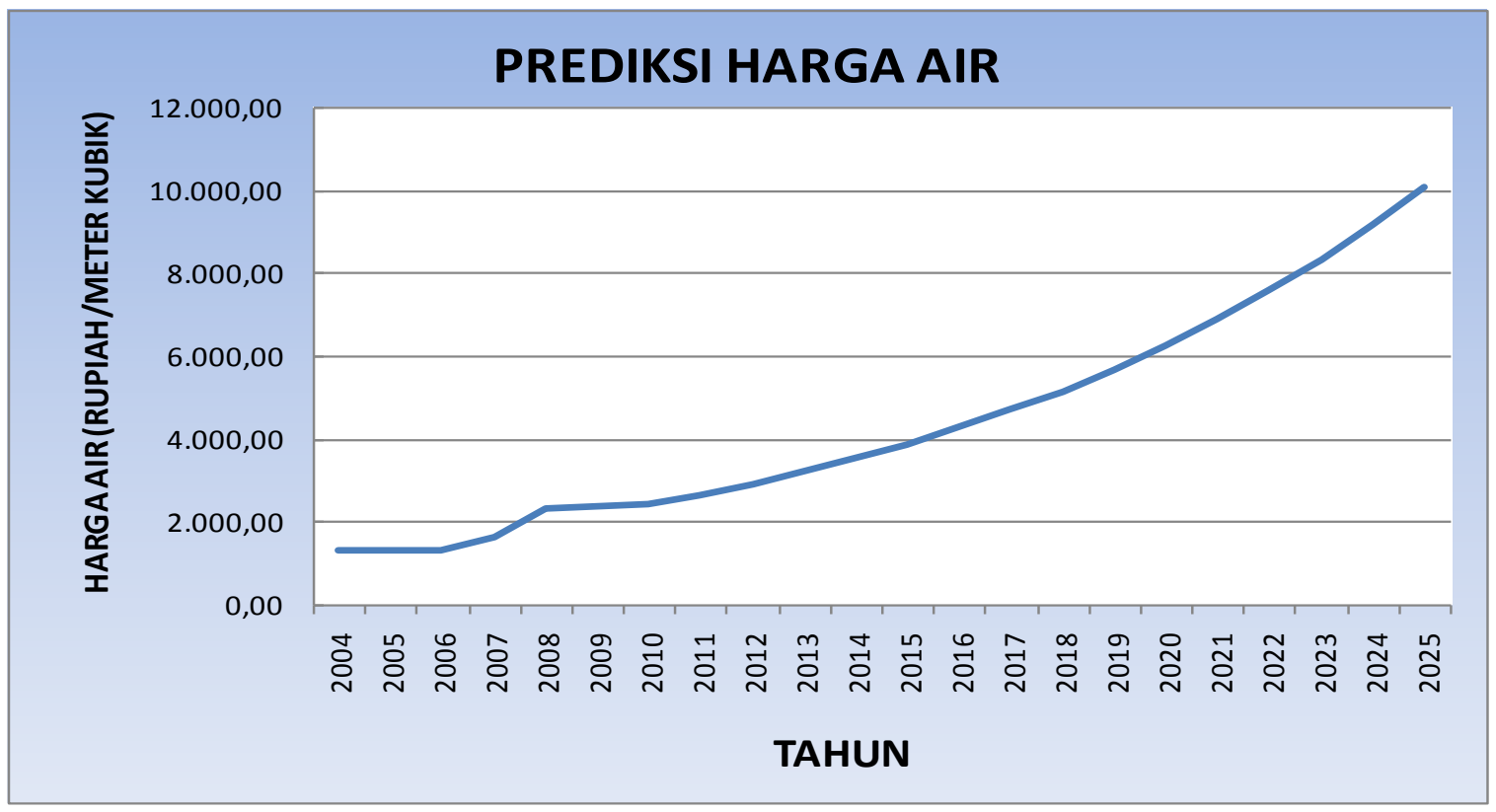

Gambar 7. Prediksi Harga Air Sampai Dengan Tahun 2025(Analisis dari Anonim 14, 2013) 


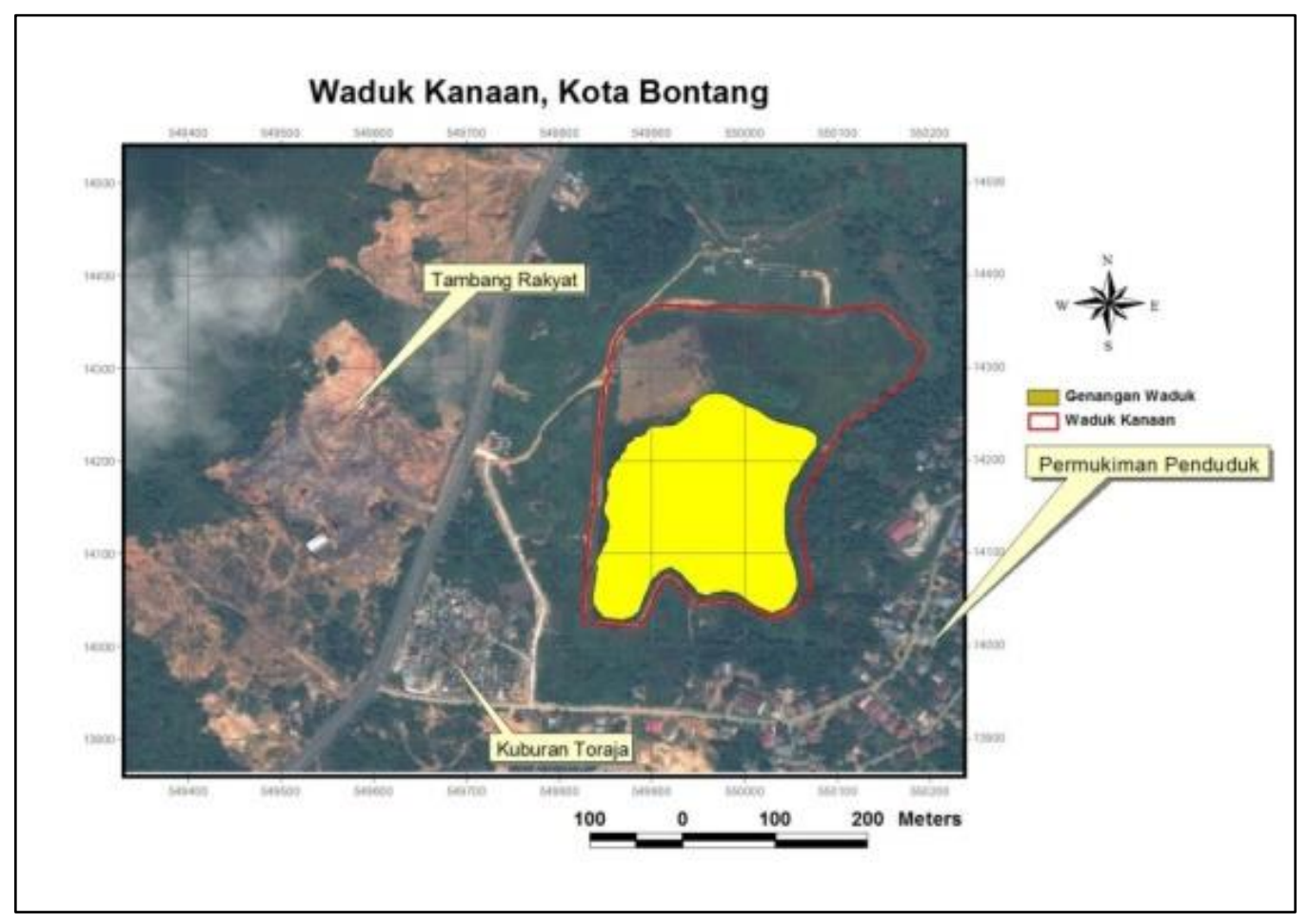

Gambar 8. Waduk Kanaan.

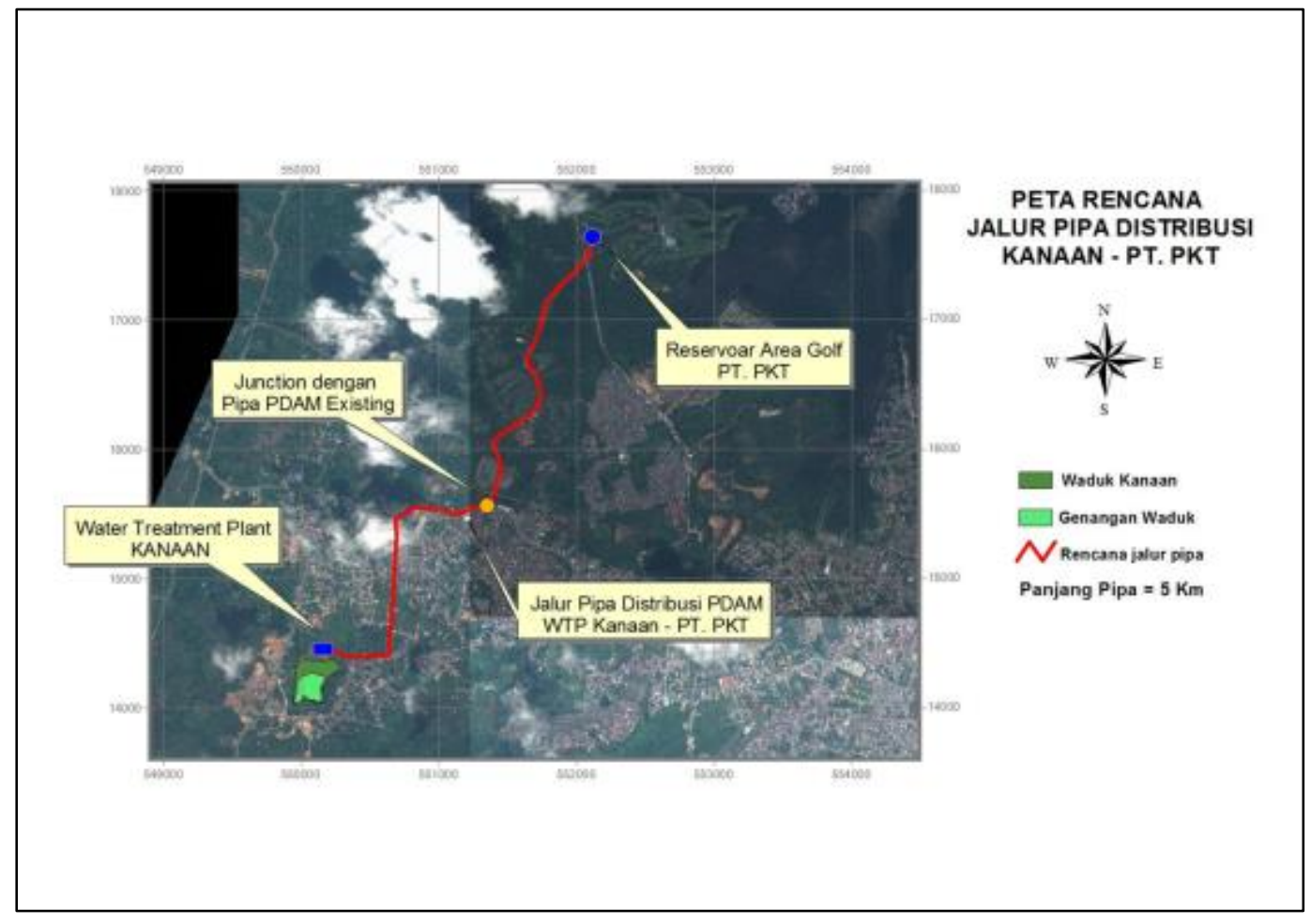

Gambar 9. Jalur Pipa Distribusi Dari WTP Menuju Servis Area. 